\title{
INTENDED AND UNINTENDED CONSEQUENCES OF INNOVATION ADOPTION: OPEN GOVERNMENT DATA ADOPTION BY THE FEDERAL DISTRICT OF BRAZIL ${ }^{1}$
}

\author{
Leonardo Ferreira de Oliveira ${ }^{2}$ \\ Carlos Denner dos Santos ${ }^{3}$
}

http://dx.doi.org/10.1590/1413-2311.214.80559

\begin{abstract}
The purpose of this paper is to discuss intended and unintended consequences regarding innovation adoption. Starting with the assumptions presented on the seminal work of Everett M. Rogers' Diffusion of Innovations, a framework to the analysis of the consequences of innovation adoption has been developed and then applied to the case of the open government data adoption by the Federal District Government of Brazil. The model is useful because it shows that different stakeholders of an innovation can perceive inversely the effects of the very same consequence, which brings new perspectives in the management of the innovation process inside a pro-innovation bias society. With the model, it is possible to analyze that some groups put pressure against innovation adoption, not because of resistance to change but because they are perceiving negative consequences related to the innovation adoption. The study presents two major contributions. First theoretical, presenting a model for analysis of the consequences of innovation adoption based on literature review and interview of specialists. Second empirical, providing a way to map the innovation adoption process

\footnotetext{
${ }^{1}$ Recebido em 25/02/2018, aprovado em 10/01/2019.

${ }^{2}$ Universidade de Brasília - Programa de Pós-Graduação em Administração e Instituto Brasiliense de Direito Público - Escola de Administração de Brasília; Brasília - Distrito Federal (Brasil) leonardo.administrador@gmail.com

${ }^{3}$ Universidade de Brasília - Programa de Pós-Graduação em Administração; Brasília - Distrito Federal (Brasil) - carlosdenner@unb.br
} 
regarding the view of the different stakeholders' roles and can be used by the private and public sector.

Keywords: Consequences of Innovation Adoption. Intended. Unintended. Open Government Data. Open Data.

\title{
CONSEQUÊNCIAS PRETENDIDAS E NÃO PRETENDIDAS DA ADOÇÃO DE INOVAÇÕES: A ADOÇÃO DE DADOS ABERTOS PELO GOVERNO DO DISTRITO FEDERAL DO BRASIL
}

\begin{abstract}
RESUMO
O objetivo deste artigo é discutir as consequências pretendidas e não pretendidas em relação à adoção de inovações. Partindo das premissas apresentadas no trabalho seminal de Everett M. Rogers (Diffusion of Innovations), uma estrutura para a análise das consequências da adoção de inovações foi desenvolvida e depois aplicada ao caso da adoção de dados abertos pelo Governo do Distrito Federal do Brasil. O modelo é útil, pois demonstra que diferentes partes interessadas de uma inovação podem perceber de forma inversa os efeitos da mesma consequência, o que traz novas perspectivas na gestão do processo de inovação dentro de uma sociedade de viés pró-inovação. Com o modelo é possível analisar que alguns grupos exercem pressão contra a adoção da inovação não pela resistência à mudança, mas por perceber consequências negativas relacionadas à adoção da inovação. $\mathrm{O}$ estudo apresenta duas contribuições principais. Primeira teórica, apresentando um modelo para análise das consequências da adoção de inovações com base em revisão de literatura e entrevistas com especialistas. Segundo empírica, fornecendo uma maneira de mapear o processo de adoção de inovações em relação à visão dos diferentes papéis exercidos pelas partes interessadas, podendo ser utilizado tanto no setor privado quanto no setor público.
\end{abstract}

Palavras-chave: Consequências da adoção de inovações. Pretendida. Não pretendida. Dados governamentais abertos. Dados abertos. 


\title{
CONSECUENCIAS PREVISTAS Y NO PREVISTAS DE LA ADOPCIÓN DE INNOVACIÓN: ADOPCIÓN DE DATOS ABIERTOS POR PARTE DEL GOBIERNO DE DISTRITO FEDERAL DE BRASIL
}

\begin{abstract}
RESUMEN
El propósito de este documento es discutir las consecuencias previstas y no previstas de la adopción de innovaciones. A partir de los supuestos presentados en el trabajo fundacional de Everett M. Rogers "Diffusion of Innovations", se ha desarrollado un marco de trabajo para el análisis de las consecuencias de la adopción de la innovación y luego se ha aplicado al caso de la adopción de datos abiertos por parte del Gobierno del Distrito Federal de Brasil. El modelo es útil porque muestra que las diferentes partes interesadas de un proceso de innovación pueden percibir de manera opuesta los efectos de una misma consecuencia, lo que aporta nuevas perspectivas en la gestión del proceso de innovación en el contexto de una sociedad con un sesgo favorable a la innovación. Con el modelo, es posible analizar que algunos grupos presionan en contra la adopción de la innovación, no por la resistencia al cambio, sino porque perciben consecuencias negativas relacionadas con la adopción de la innovación. El estudio presenta dos grandes contribuciones. La primera teórica, presentando un modelo para el análisis de las consecuencias de la adopción de la innovación basado en la revisión de la literatura y entrevistas a especialistas. El segundo empírico, al proporcionar una manera de mapear el proceso de adopción de la innovación con respecto a la visión de los diferentes papeles de las partes interesadas y que puede ser utilizado por el sector privado y el sector público.
\end{abstract}

Palabras clave: Consecuencias de la adopción de la innovación. Previstas. No Previstas. Datos de Gobierno Abiertos. Datos Abiertos.

\section{INTRODUCTION}

The search for innovation has required considerable effort from entrepreneurs, policymakers and scholars to add more value to products or services delivered. Some take as the remedy for every kind of organizational dysfunction as well as the solution to social problems and lack of competitiveness (BAREGHEH; ROWLEY; SAMBROOK, 2009; BESSANT; TIDD, 2007; WOLFE, 1994). However, despite the remarkable role played by innovations as a key factor in the evolution of mankind (TIGRE, 2014), this approach does 
not encompass all the characteristics of this phenomenon, given that intended and unintended consequences stem from innovation adoption (ROGERS, 2003; SVEIBY et al., 2009; SVEIBY; GRIPENBERG; SEGERCRANTZ, 2012; ZUIDERWIJK; JANSSEN, 2014a).

However, studies that address the implications of adopting innovations are rare, with a predilection for studies that address the positive aspects of these innovations, with some exceptions that focus only on the negative aspects (ABRAHAMSON, 1991; FONTENELLE, 2012; TARAFDAR; GUPTA; TUREL, 2015). In this regard, the understanding of the phenomenon in all its amplitude can contribute to give voice to minorities, forgotten or neglected groups, which is particularly important regarding the actual context where governments are trying to use public sector innovation to solve complex problems (DE VRIES; BEKKERS; TUMMERS, 2016; KARO; KATTEL, 2016; KATTEL et al., 2014).

In summary, monitoring the consequences of innovation adoption, considered in their entirety (intended and unintended effects), can potentially help in dealing with the challenges of the current organizational dynamics in a planned, rather than improvised and emergency way, contributing for a better understanding of the conflicts arising from the adoption of innovations and their influence on the different stakeholders.

In this regard, Rogers' Diffusion of Innovations Theory - DIT (ROGERS, 2003) provides the foundations to analyze the consequences of innovation adoption. Another aspect that calls attention is the importance of the viewpoint of whoever is having the impact of the innovation adoption (ROGERS, 2003; SVEIBY et al., 2009) and, therefore, the Stakeholder Theory (FREEMAN, 1984; FREEMAN; REED, 1983; MITCHELL; AGLE; WOOD, 1997) provides a supportive framework for the understanding of the phenomenon. Hence, this work revisits de seminal work Diffusion of Innovations from Everett Rogers (2003) - whose first edition was published in 1962 - focusing on consequences of innovation adoption to discuss that whether an innovation is positive or negative depends on the viewpoint of the stakeholders which are suffering its consequences, proposing a model to analyze it based on stakeholders' roles.

The adoption of open data by the public sector comprises a relevant space for testing the model, considering that it presents the necessary maturity to evaluate the innovation up to the moment. Since 2009, after President Obama's Open Government and Transparency Memorandum (OBAMA, 2009), several open data initiatives have been developed around the world following the open government movement (CABINET OFFICE UK, 2012; DESA, 2013; OECD, 2016; OGP, 2011; THE WORLD BANK, 2014). These initiatives provided a uniformity of expectations regarding the open data adoption but qualitative studies are needed 
to demonstrate how the impacts of open data adoption are indeed perceived by different groups of stakeholders (DAWES; VIDIASOVA; PARKHIMOVICH, 2016; ZUIDERWIJK et al., 2012; ZUIDERWIJK; JANSSEN, 2014b).

A qualitative case study of the adoption of Open Data by the Federal District Government of Brazil is presented to illustrate with evidence the arguments presented. The case of the Federal District is relevant given the unique role of this entity of the Brazilian federation, which develops activities typical of municipalities and states at the same time. Also, the option for this case is justified by the degree of maturity obtained by the administrations of the Federal District, which under different managements have maintained their commitment to transparency and open data, since 2012.

Besides this introduction, this paper presents four parts. Initially, the theoretical background presents the main concepts about innovations and its consequences, followed by a discussion regarding stakeholders' roles of innovation projects and the open government data context. Then, the methodology is presented. Next, the emphasis is given to the data analysis and discussion, followed by final considerations and references.

\section{THEORETICAL BACKGROUND}

\subsection{CONSEQUENCES OF INNOVATION ADOPTION AND STAKEHOLDERS' ROLES}

To Schumpeter (1934), technological change drives development, revolutionizing the economic structure in a process of new combinations which explains the economic cycles (DOSI, 1984; FREEMAN; SOETE, 1997; NELSON; WINTER, 1977, 1982; ROSENBERG, 1982; SCHUMPETER, 1934). Innovation plays a key role in this context, acting as a "creative destruction" of products and markets (SCHUMPETER, 1934) and functioning as a trend in which its positive effects usually stand out from the negatives (FONTENELLE, 2012). However, current market dynamics involve a wide range of actors and because of that a model to analyze the consequences of innovation adoption to different stakeholders' roles, including its positive and negative characteristics, would be of great value (SVEIBY et al., 2009; SVEIBY; GRIPENBERG; SEGERCRANTZ, 2012).

In this regard, Rogers' Diffusion of Innovations Theory - DIT (2003) provides the foundation for the development of a comprehensive model to analyze the consequences of innovation adoption. To Rogers (2003), it does not matter if the idea is really new from the viewpoint of when it was first used or discovered. That is, if the idea seems new to the 
adopter, its use is an innovation. The author presents in the DIT a definition for the consequences innovation adoption as "changes that occur to an individual or to a social system as a result of the adoption or rejection of an innovation" (ROGERS, 2003). To Rogers it can be categorized according to three dimensions: (1) Desirable Versus Undesirable Consequences; (2) Direct Versus Indirect Consequences; and (3) Anticipated Versus Unanticipated Consequences.

To Rogers (2003, p. 442-446), 'Desirable Consequences' are 'the functional effects of an innovation to an individual or to a social system"; while 'Undesirable Consequences' are "the dysfunctional effects of an innovation to an individual or to a social system." The author also explains that 'Direct Consequences' are "the changes to an individual or a social system that occur in immediate response to an innovation" while 'Indirect Consequences' are "the changes to an individual or a social system that occur as a result of the direct consequences of an innovation". Rogers (2003, p. 448) clarify that 'Anticipated Consequences' are "changes due to an innovation that are recognized and intended by the members of a social system"; while 'Unanticipated Consequences' are "changes due to an innovation that are neither intended nor recognized by the members of a social system."

According to Rogers (2003), despite the importance of the consequences of innovations, they have received little attention from researchers as well as from the agents of change, the ones who should recognize their responsibility for the consequences of the innovations they introduced. Some researchers have argued about the importance of tackling the pro-innovation bias by addressing the negative aspects of innovation adoption (BAWDEN; ROBINSON, 2009; MARKUS; MENTZER, 2014; TARAFDAR et al., 2015; TARAFDAR; GUPTA; TUREL, 2015).

We argue that to a better understanding of the positive and negative consequences of innovation adoption it is needed to know to whom these consequences are affecting. This condition led us to develop a framework that considers the main stakeholders' roles in the consequences of innovation adoption.

Freeman (1984, p. 46) characterizes stakeholders as "any group or individual who can affect or is affected by the achievement of the organization's objectives," giving rise to the awareness of the influence of various players over organizations. This aspect was not considered by companies in the past, which focus relied on the shareholder or owner as the main justification for the organizational action. According to Freeman and Reed (1983) there are other groups for which the organization is responsible, such as employees, customers, suppliers, funders and society, and these groups also have influence over organizational 
action. This notion is important because it is expected that stakeholders perceive the consequences of the innovation adoption differently and therefore they should be accounted for in the change process (JANSSEN; CRESSWELL, 2005).

Also, the influence stakeholders have in the desired outcomes can be seen as an essential concern regarding innovation adoption (JANSSEN; CRESSWELL, 2005). This matter was developed in the work of Mitchell, Agle, and Wood (1997), where the authors worked on the concept of salience - the degree to which managers prioritize conflicts of stakeholder demands. The concept is useful in order to answer to whom the consequences of the innovation adoption concern, since, managers should be aware of the existence of bias regarding the adoption process (DE VRIES; TUMMERS; BEKKERS, 2017).

Worth to mention that although the stakeholder theory was initially grounded in the private sector its use has been widely done in the public sector as well, where the main argument for the usefulness of its practice is related to the range of stakeholders involved in the public sector projects (AXELSSON; GRANATH, 2018). Also, although the Stakeholder Theory (FREEMAN, 1984; FREEMAN; REED, 1983; MITCHELL; AGLE; WOOD, 1997) was developed within a global vision of the organization, its use fits situations in which several stakeholders take a position regarding a particular issue and are interested and can express a preference, such as in the case of innovation projects (TROSHANI; DOOLIN, 2006; VOS; ACHTERKAMP, 2006).

In this sense, Vos and Achterkamp (2006, p. 167), in a discussion about classifications model to the innovation context, present the following key roles: (a) Client - "the party whose purposes are being served through the innovation"; (b) Decision maker - "sets requirements regarding the innovation and evaluates whether the innovation meets these requirements"; (c) Designer - contributes with "expertise to the innovation process and is responsible for the (interim) deliverables"; and (d) Passively involved/ representative - "is affected by the outcomes of the innovation project without being able to influence these outcomes. A representative is a person who has been selected to act on behalf of another, i.e. the passively involved."

Two models to analyze the consequences of innovation adoption with the use of the stakeholder theory were found and provided insights for this study. The model of Bloomrosen et al. (2011) provides an indication that the analysis of the consequences should be directed to a specific innovation. The authors conducted studies of the undesirable consequences of adopting information technology in health services, taking advantage of the classification made by Rogers (2003), as well as the studies of Ash, Sittig, Dykstra et al. (2007). 
In the other study, Sveiby et al. (2012) developed the analysis of undesirable and unanticipated aspects of innovations. However, a criticism of the model of Sveiby et al. (2012) concerns the eminent focus on the dysfunctions of innovations while we believe that to analyze the consequences of innovations, one cannot choose the side of the desirable consequences or the side of the undesirable consequences, just as we cannot talk about the cost-benefit of something without knowing the cost or without knowing the benefit. We argue that there is a systemic relationship between consequences of innovation adoption and in order to comprehend it both sides need to be understood, as the two sides of the same coin. In this regard, the open government data context presents a good domain to focus on for the reasons we explain next.

\subsection{OPEN GOVERNMENT DATA}

Open Data concerns the active publication of primary data that is complete and updated, in reusable format and license free, with a view to increasing transparency and social participation in pursuit of mutual benefits (both for the organizations that open their data and those that use the open data). As defined by Sadic and Indulska (2017, p. 150), "open data is data made freely available by governments, organizations, researchers, among others, for use by anyone without copyright restrictions."

The concept applies to both the private sector and public sector but has become extremely popular in the second one after the publication of the President Obama's Open Government and Transparency Memorandum (OBAMA, 2009), given its main role within the open government movement (GONZALEZ-ZAPATA; HEEKS, 2015). In this context, open data can be called open government data. As conceptualized by the Open Knowledge Foundation, Open Government Data is the "data produced or commissioned by government or government-controlled entities" which "can be freely used, modified, and shared by anyone for any purpose" (OKF, 2012, [s.d]), where data should be primary, timely, complete, machine-readable, accessible, non-discriminatory, license-free and non-proprietary (SAXENA; JANSSEN, 2017).

Although the increased interest the topic has had in the last years, there is little knowledge related to the intended and unintended effects of open government data (SAXENA; JANSSEN, 2017). One exception can be seen in the work of Janssen et al. (2012), where the authors argue that open government data can reinforce and transform institutional structures and for this reason, benefits and barriers emerge from open data. 
However, as Zuiderwijk et al. (2018) draw attention, open government data initiatives are criticized for not taking into account the view of main stakeholders and due to the lack of empirical evidence of its effects.

Some of the main benefits of open data were categorized by Janssen et al. (2012): (1) political and social - for example, accountability and public engagement; (2) economic - for instance, stimulation of innovation and economic growth; and (3) operational and technical for example, optimization of administrative process and data reuse. Nevertheless, as Jetzek (2016) points out, several challenges can be seen in open government data initiatives, like poor data quality and interoperability, lack of internal capabilities, problems regarding governance and political agendas. Indeed, intended and unintended aspects arise from open government data initiatives but empirical studies that try to capture both sides are rare.

Thus, based on the literature surveyed, a Model for Analysis of the Consequences of Innovation Adoption was developed and applied to the open government data adoption by the Federal District Government of Brazil, as shown below.

\section{METHODOLOGY AND MATERIALS}

The research was divided into two moments, chronologically distinct, after the literature review. First, we sought to collect the opinion of $\mathrm{PhDs}$ with research in the innovation field to refine the model developed. Second, the model was applied to the case of the open data adoption by the Federal District Government of Brazil. Thus, based on the theoretical background, a preliminary conceptual Model for Analysis of the Consequences of Innovation Adoption was constructed. Then, a semi-structured interview was conducted with a group of nine professionals in the innovation research field, as a way to refine the Model questions and objectives are presented in Table 1. Next, a semi-structured interview was conducted with another group, aimed at analyzing the opinion of stakeholders and the consequences of the adoption of Open Data by the Federal District Government of Brazil GDF - using questions and objectives presented in Table 2. 


\begin{tabular}{ll}
\hline \multicolumn{1}{c}{ Questions } & \multicolumn{1}{c}{ Objectives } \\
\hline & $\begin{array}{l}\text { To verify the experience of the respondent, } \\
\text { who together with the questioning about the } \\
\text { academic formation were the two variables of } \\
\text { 1. Could you talk about your experience with } \\
\text { the innovation theme? }\end{array}$ \\
& in the research.
\end{tabular}

2. According to Rogers (1995) and Sveiby (2012), few studies are aimed at understanding the consequences of innovations, being generally the focus of innovation studies the moment before the adoption of a certain innovation. Considering the moment after the adoption of an innovation, what do you think of the model presented?

3. Could you think of an innovation and apply it to the model?

4. On the typology of consequences presented by Rogers (2003), in your opinion, is there something significant missing? 5. Do you believe that the four stakeholder roles presented by Vos and Achterkamp (2006) encompass all possible stakeholders of innovations?

6. Suggestions? Final considerations?

Present the model developed as well as the main authors used and collect the impression of the interviewees on the model.

Exercise the use of the model through simulation.

Validate the use of the typology of consequences presented by Rogers (2003) and collect suggestions for improvement. Validate the stakeholder roles presented by Vos and Achterkamp (2006) and collect suggestions for improvement.

Collect other observations from the interviewees about the model that might have been left out of the other questions.

Source: elaborated by the authors.

In both cases, initially the interview audio was transcribed with the aid of Express Scribe Transcription Software Pro. Then, the data of the transcribed interviews were analyzed using the RQDA software ( $\mathrm{R}$ programming language package). The data was analyzed through content analysis, as recommended by Bardin (2011). Thus, in the pre-analysis phase, the documents to be submitted for analysis were established, objectives were formulated, and indicators defined to provide the grounds for the final interpretation. Then, with the aid of the RQDA software, the material was explored, through execution of coding and categorization procedures.

REAd | Porto Alegre - Vol. 25 - No 1 - Janeiro / Abril 2019 - p. 1- 25 
Table 2 - Questions and Objectives of the GDF Open Government Data Interview

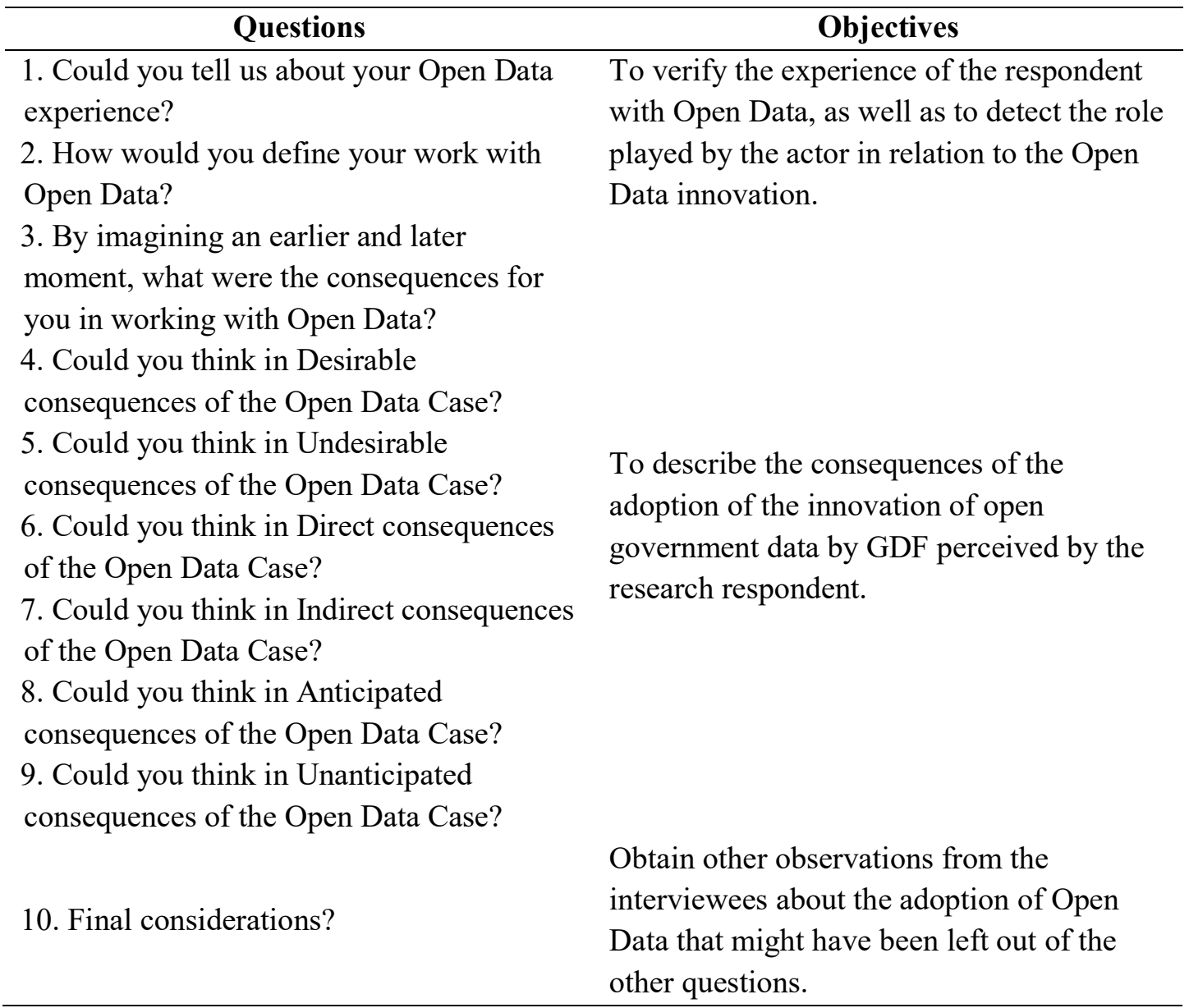

Source: elaborated by the authors.

\section{DATA ANALYSIS AND DISCUSSION}

Altogether, nine interviews were conducted with the PhDs, totaling approximately 6 hours of recorded audio. Upon conclusion of the analysis procedures, 351 registration units (themes) were found and grouped into categories related to the background of the interviewee, the consequences of innovation adoption used in the model and the roles of stakeholders. For example, one registration unit categorized in the Client stakeholders' role was: "I think there is a lack of a previous stage here, which is the input, from which comes the need to generate an innovation, who causes change" (I5). Another example about stakeholders' role is: "I am missing here relations with not necessarily direct Stakeholders, but agents that influence at a level of a broader institutional environment, for example, competitors, competing companies, rules, government regulation mechanisms, the role of government" (I1). 
It should be noted that the total number of respondents (nine) was determined by theoretical saturation of the pre-formulated categories (Table 3), following the recommendation for two additional interviews to be carried out after the meeting of the saturation point (THIRY-CHERQUES, 2009).

Table 3 - Saturation Point of Analysis Model Validation Interviews

\begin{tabular}{cccccccccc}
\hline Categories & I1 & I2 & I3 & I4 & I5 & I6 & I7 & I8 & I9 \\
\hline $\begin{array}{c}\text { Stakeholders } \\
\begin{array}{c}\text { Consequences of Innovation } \\
\text { Adoption }\end{array}\end{array}$ & 1 & 1 & 1 & 0 & 1 & 1 & 0 & 0 & 0 \\
\hline
\end{tabular}

Source: elaborated by the authors.

As a result, it was possible to propose a Model for Analysis of the Consequences of Innovation Adoption, as presented in Figure 1.

Figure 1 - Model for Analysis of the Consequences of Innovation Adoption

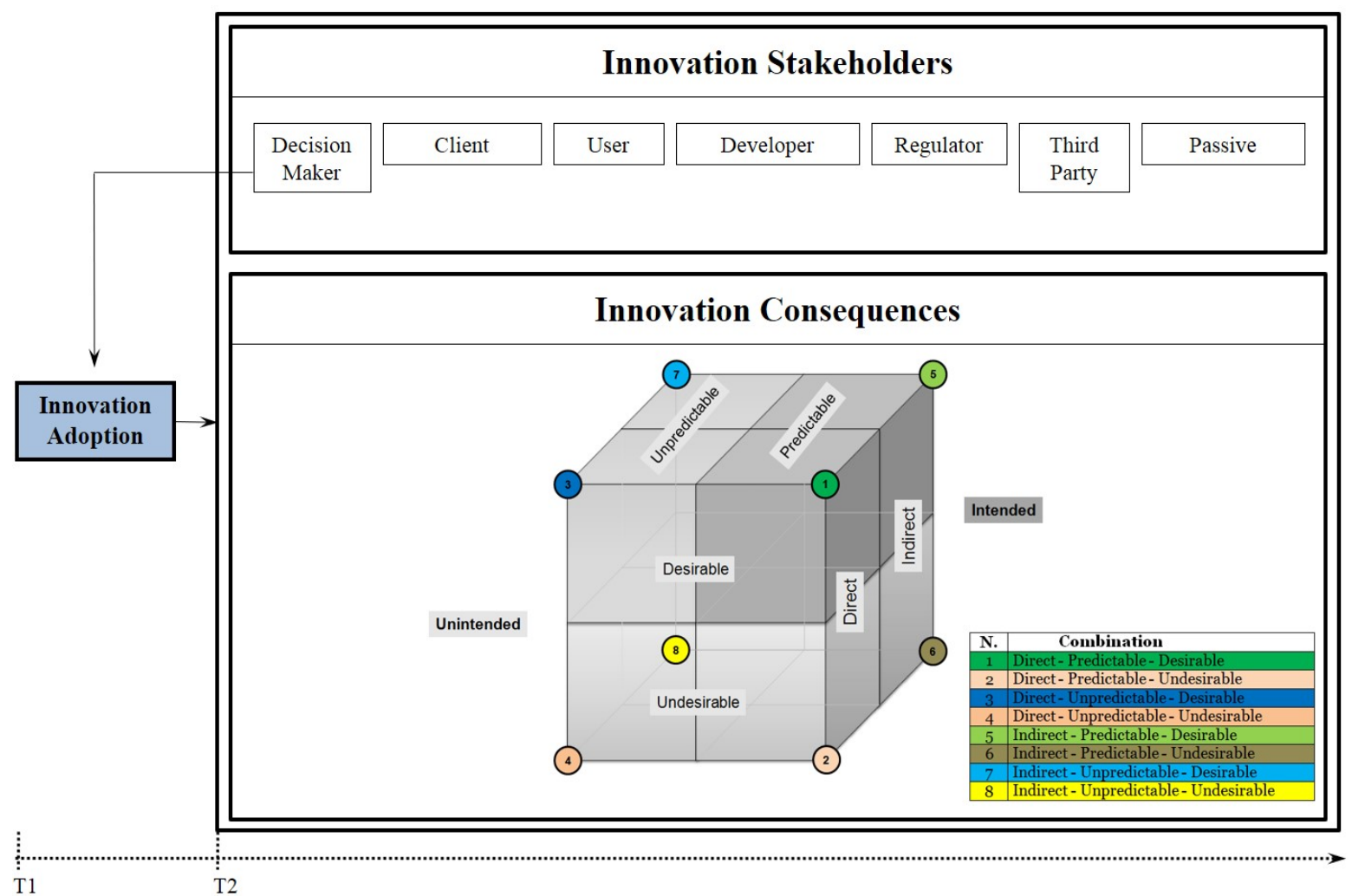

Source: elaborated by the authors.

REAd | Porto Alegre - Vol. 25 - No 1 - Janeiro / Abril 2019 - p. 1- 25 
The concepts regarded Innovation Stakeholders in Figure 1 are: (a) Decision maker decides whether an innovation will be adopted, based on the analysis of the requirements; (b) Client - establishes the requirements of innovation; (c) User - uses innovation; (d) developer contributes to the development of innovation; (e) Regulator - influences innovation through rules and regulations; (f) Third party - can influence the results of innovation both positively and negatively, but does not fit the other classifications; and (g) Passive - is affected by the results of innovation, without being able to influence these results.

The concepts regarded Consequences of Innovation in Figure 1 are: (a) Desirable Consequences - those that represent the functional effects of an innovation for an individual or a social system; (b) Undesirable Consequences - they are related to the dysfunctional effects of an innovation for an individual or a social system; (c) Direct Consequences - the changes to an individual or social system that occur in immediate response to the adoption of an innovation; (d) Indirect Consequences - they are related to changes to an individual or social system arising from the direct consequences of an innovation; (e) Predictable Consequences - the changes resulting from innovations that can be anticipated at the time of adoption; (f) Unpredictable Consequences - the changes resulting from innovations that cannot be anticipated at the time of adoption; ( $\mathrm{g}$ ) Intended Consequences - consequences that are necessarily predictable and desirable; and (h) Unintended Consequences - consequences that are not predictable and desirable simultaneously, and that may be either predictable or desirable.

To better illustrate the possible combinations of consequences and their dynamics, a cube was drawn in Figure 1, wherein each dichotomy is located on its face and its counterface, so that each corner of the cube provides one of the 8 kinds of different combinations of Desirable and Undesirable, Direct and Indirect, Predictable and Unpredictable consequences. It was named ACIA Cube (Cube for Analysis of the Consequences of Innovation Adoption).

The ACIA Cube allows us to demonstrate another important aspect regarding the dynamics of consequences over time, which can lead to a given consequence changing between different possibilities at different times. Thus, with support from the work of Vos and Achterkamp (2006), which sets out four stages for an innovation project, it is understood that over time certain consequences move between different possibilities for each of the stakeholders, demonstrating that the understanding of certain consequences may change for stakeholders over time (Figure 2) in different levels (TARAFDAR; GUPTA; TUREL, 2015), a situation that can be apprehended with the systematic use of the Model for Analysis of the Consequences of Innovation Adoption. 


\section{Figure 2 - Visual representation of possible variation of the ACIA Cube over time for each stakeholder}

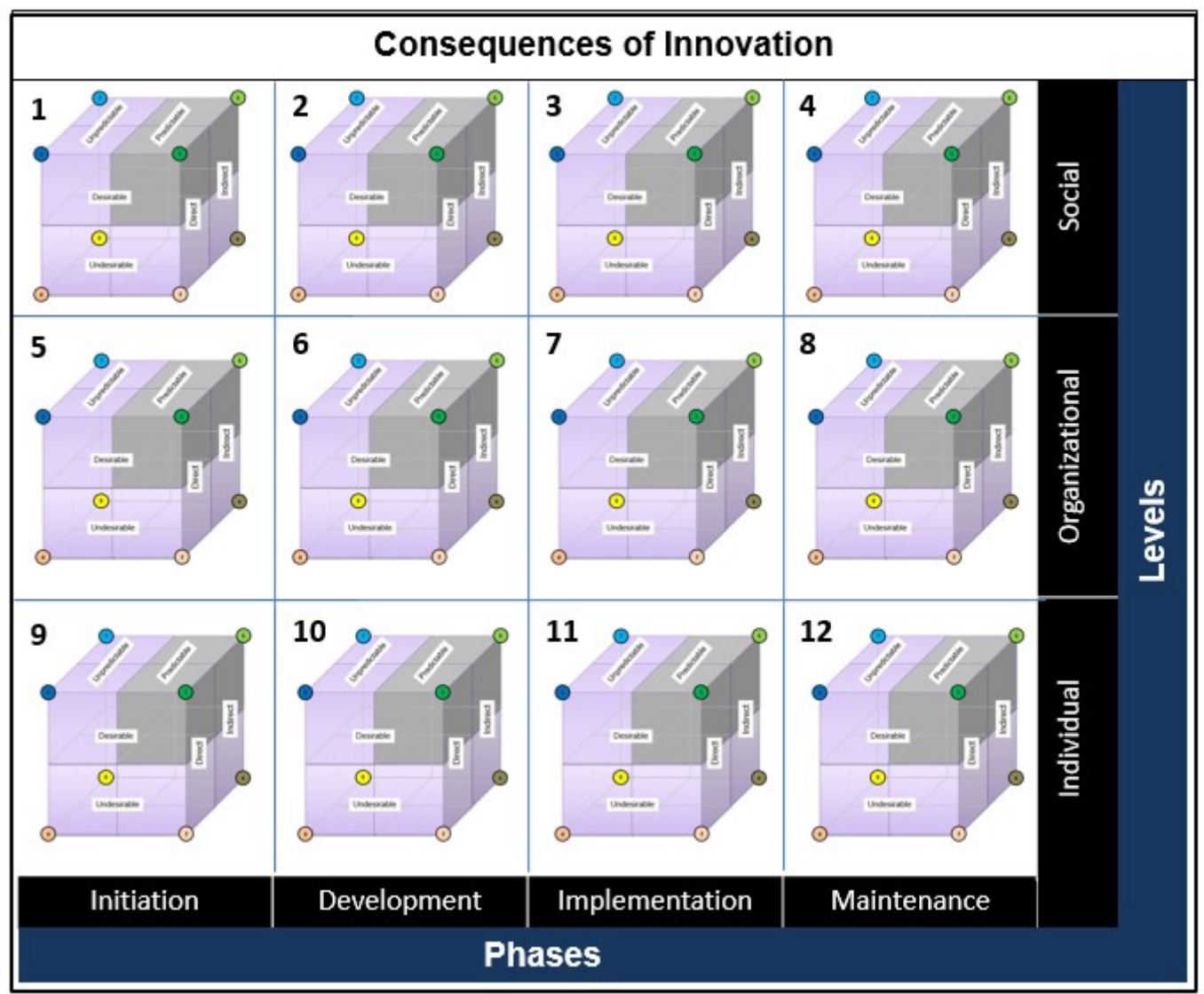

Source: elaborated by the authors.

After refining the Model for Analysis of the Consequences of Innovation Adoption, it was used to evaluate the adoption of open government data by the Federal District Government of Brazil - GDF. As a context, in Brazil, the enactment of Law no. 12,527, of November 18, 2011, known as the Law on Access to Information - LAI, encouraged several similar initiatives in the state scope for accessing data and public information. In the Federal District, the theme was regulated by Law No. 4,990, of December 12, 2012, encouraging the use of open data in different areas of government, with the intention of improving transparency and centralizing the search and access of public data and information, in order to make possible initiatives of applications, analyzes, comparisons and visualizations of information (paid or free).

Interviews were conducted with at least one representative of each of the roles described in the model involved with this innovation, namely: Decision maker, Client, User, Developer, Third party and Passive. The Decision maker was the first to be interviewed, and 
through him, in a snowball technique, other stakeholders were identified. It should be noted that the information regarding the consequences attributed to the Regulator stakeholder was obtained from a documental report by an entity that disseminates standards for open data use. Altogether, seven interviews were conducted, totaling about 5 hours of recorded audio.

After the analysis procedures were carried out, ninety-five consequences of the adoption of open government data by the Federal District Government of Brazil were found, mentioned spontaneously by respondents. Each one of the consequences was analyzed according to the typology of consequences of innovation adoption developed in the analysis model, i.e. classified as direct or indirect, predictable or unpredictable, desirable or undesirable consequence. Another aspect to be highlighted concerns the total of consequences for each possibility of the typology, for every corner of the ACIA Cube. Thus, the frequency was counted and percentages demonstrated for the case of open data in GDF, according to Table 4.

It should be noted, in Table 4, that Indirect consequences were mentioned more frequently than Direct ones, $63,2 \%$ versus $36,8 \%$, an aspect which can be attributed to the possibility of indirect consequences having several generations of effects over time, as pointed out in the work of Sveiby et al. (2012).

The greatest discrepancy between categories was found in the Predictable types, $74,7 \%$, and Unpredictable types, with $25,3 \%$. This, together with observations on the Desirable types, $56,8 \%$, and Undesirable types, $43,2 \%$, leads to the conclusion that if most consequences are known in advance and still a large number of them is undesirable, many of the consequences of innovation adoption are treated as trade-offs, as raised by Ash, Sittig, Dykstra et al. (2007) and Bloomrosen et al. (2011).

Still on the Desirable types, $56,8 \%$, and Undesirable types, $43,2 \%$, the percentage proximity of observations in both cases drew attention. Given the literature raised about the pro-innovation bias (ABRAHAMSON, 1991; ROGERS, 2003; SVEIBY et al., 2009), it was expected that the Desirable observations would top the undesirable, an aspect that was not found in the case under study.

Another important aspect concerns the almost equal division between Intended consequences, 52,6\%, and Unintended ones, 47,4\%, for although 6 of the 8 possible combinations concern the Unintended consequences, the 2 possible combinations of the Intended consequences are still more frequent.

It should be noted that the findings are not consistent with generalization 11-2 of Rogers (2003), in which the author states that Undesirable, Indirect and Unpredictable 
consequences generally appear together, as do the Desirable, Direct and Predictable consequences. In the case of the study in question, the percentage sum of the two possibilities is equal to $22,1 \%$ of the raised consequences $(11,6 \%+10,5 \%)$, counting the other possibilities which are beyond the generalization with $77,9 \%$ of the observations.

\section{Table 4 - Frequency for each type of consequence of ACIA Cube found in the case of Open Data in the Federal District Government of Brazil}

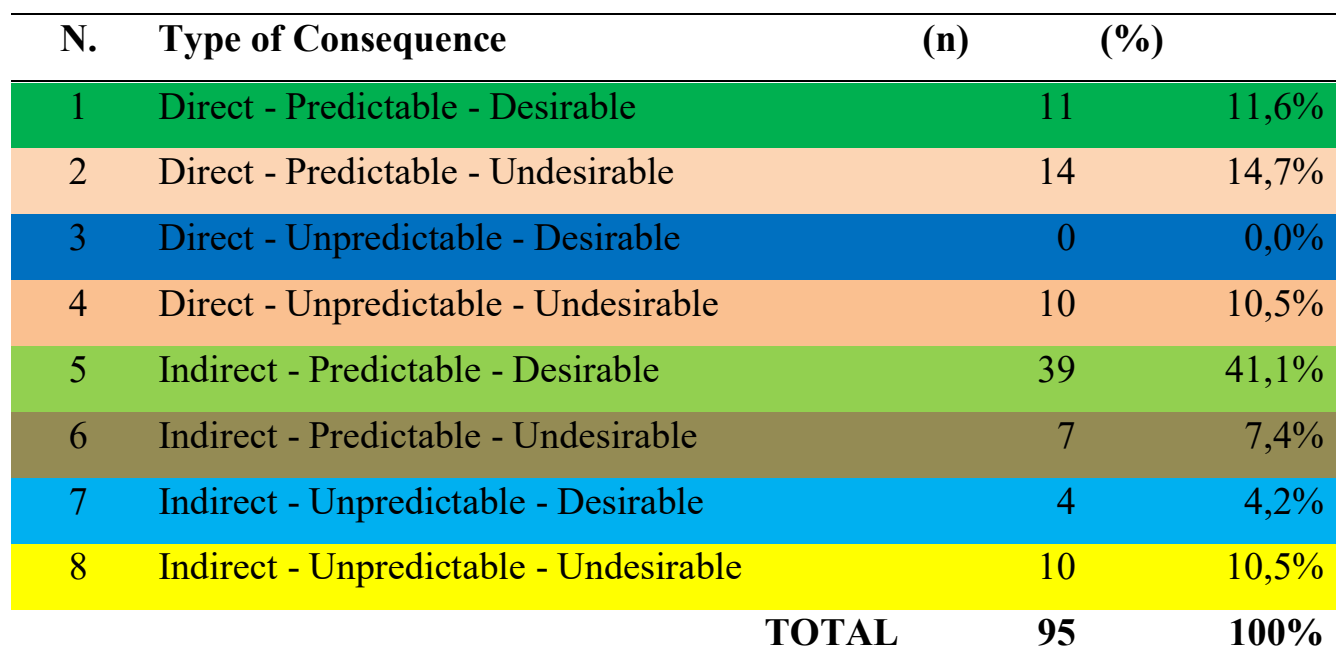

Source: elaborated by the authors.

The possibility with the lowest number of occurrences referred to Direct, Unpredictable and Desirable consequences, which were not mentioned in the context of this study. On the other hand, the most frequent consequences were Indirect, Predictable and Desirable, with 39 mentions, representing $41,1 \%$ of the findings. This appears to refer to the type of innovation studied, since, as emerged in the interviews, Open Data encourage participation and social control.

Upon grouping the consequences, given that different stakeholders mentioned the same consequence in some cases, it was possible to arrive at 57 consequences that, together with the validated typology, made it possible to analyze the relations between the Stakeholders and the consequences of adopting the Open Data innovation in the Federal District. The consequences are shown in Figure 3, which summarizes in a single image how the types of consequences indicated are perceived by the different stakeholders interviewed, named Map of Consequences of Open Data Adoption by the GDF.

With the aid of the map, one can immediately see some issues. To start, it is noted that a color scheme was used to better demonstrate how different perceptions of the stakeholders 
are perceived in relation to the whole of the consequences. Thus, the consequences were ordered with the highest number of citations at the top, and the lines were subtracted from the image to ensure visual fluency.

From the beginning, it is possible to see the difference between the quadrants dark and light green and the other quadrants. The quadrants in green color (type 1 and 5 squares of the ACIA Cube) are the Intended consequences, while the others correspond to the Unintended consequences. The dark blue color is not present on the map, meaning the absence of Direct, Unpredictable and Desirable consequences (type 3 square of the ACIA Cube), as already mentioned. The type 7 of the ACIA Cube (color light blue) consequence has only 4 observations; they are happy surprises according to Ash, Sittig, Dykstra et al. (2007), characterizing Indirect, Unpredictable and Desirable consequences.

The perception of the different stakeholders regarding some consequences is also similar. On 7 occasions, at least three different stakeholders claimed to perceive the same consequence, which can be seen in lines $1,3,4,5,6,8$ and 10. We can also see when full alignment is missing among all the stakeholders regarding the same consequence, a fact that occurs 6 times in the 57 occurrences raised, totaling about $10 \%$ of occurrences with different consequences for different stakeholders, which can be observed in lines 1, 2, 5, 7, 9 and 17, which relate, respectively, to the following consequences: Competition for visibility of transparency resulting from open data; Intra-organizational conflicts; Possibility of providing intelligible information to any citizen, even citizens not specialized in data handling (intelligibility); Demonstration of budget limitations for investment in Open Data; Little demand for open data already available (low social engagement); and Contract with NGOs for diagnosis aimed at implementation of an Open Data policy.

In the case of line 1, the consequence with the greatest number of mentions (five), which addresses Competition for visibility of transparency resulting from open data, a dispute was found between areas of government that were considered unpleasant by all respondents. The difference is that for one of them the consequence was Direct and for the others Indirect. In line 2, the consequence of intra-organizational conflicts was detected. Such conflicts arise from technical changes, political definitions and mental paradigms associated with the use of Open Data. 


\section{Figure 3 - Map of Consequences of Open Data Adoption by the Federal District Government of Brazil}

\begin{tabular}{|c|c|c|c|c|c|c|c|}
\hline N. & Consequences & $\begin{array}{c}\text { Decision } \\
\text { maker }\end{array}$ & $\begin{array}{c}\text { Client / } \\
\text { User }\end{array}$ & Developer & Regulator & $\begin{array}{l}\text { Third } \\
\text { party }\end{array}$ & Passive \\
\hline 1 & $\begin{array}{l}\text { Competition for visibility to be known as "the agency" that promotes } \\
\text { transparency with open data }\end{array}$ & & & & & & \\
\hline 2 & Intraorganizational conflicts & & & & & & \\
\hline 3 & Promotion of social control & & & & & & \\
\hline 4 & Encouraging social participation & & & & & & \\
\hline 5 & $\begin{array}{l}\text { Possibility of providing intelligible information to any citizen, even if not } \\
\text { specialized in data manipulation (intelligibility) }\end{array}$ & & & & & & \\
\hline 6 & Search for value-in-use information (Usability) & & & & & & \\
\hline 7 & Demonstration of budgetary constraints on Open Data investment & & & & & & \\
\hline 8 & $\begin{array}{l}\text { Demonstration of the lack of control in the monitoring of specific } \\
\text { databases (lack of reliability in the data) }\end{array}$ & & & & & & \\
\hline 9 & Low demand for available open data (low social engagement) & & & & & & \\
\hline 10 & $\begin{array}{l}\text { Problems of IT Infrastructure (inappropriate links, server switching, } \\
\text { system administrator issues) }\end{array}$ & & & & & & \\
\hline 11 & Contribution to education & & & & & & \\
\hline 12 & Demonstration of inability to deliver certain data & & & & & & \\
\hline 13 & $\begin{array}{l}\text { Demonstration of the need to better organize the information (data and } \\
\text { metadata) }\end{array}$ & & & & & & \\
\hline 14 & Decreased demand for passive transparency & & & & & & \\
\hline 15 & Purposeful unavailability of particular data & & & & & & \\
\hline 16 & Need to make APIs available to developers of data solutions & & & & & & \\
\hline 17 & Agreement with NGOs for diagnosis to implement an Open Data policy & & & & & & \\
\hline 18 & Maturation of Open Data Movements & & & & & & \\
\hline 19 & Analyzes from open data & & & & & & \\
\hline 20 & Absence of political signs of how public information is treated & & & & & & \\
\hline 21 & Advancement in the maturity of the use of Open Data & & & & & & \\
\hline 22 & Interorganizational collaboration & & & & & & \\
\hline 23 & Interorganizational conflicts & & & & & & \\
\hline 24 & $\begin{array}{l}\text { Confusion over communication channels to get certain information } \\
\text { requests }\end{array}$ & & & & & & \\
\hline 25 & Formal channel creation for public data demands & & & & & & \\
\hline 26 & Dysfunction in updating Open Data & & & & & & \\
\hline 27 & $\begin{array}{l}\text { Demonstration of the absence of punishment mechanisms if the } \\
\text { information is not made available according to legal precepts }\end{array}$ & & & & & & \\
\hline 28 & $\begin{array}{l}\text { Demonstration of the impossibility of control and inspection of contracts } \\
\text { and their additives }\end{array}$ & & & & & & \\
\hline 29 & Providing misinformation & & & & & & \\
\hline 30 & Disputes in communities for visibility in demanding Open Data & & & & & & \\
\hline 31 & Evidence of the relationship between State and Society & & & & & & \\
\hline 32 & Evolution of features related to Open Data & & & & & & \\
\hline 33 & Ease of Access to Open Data & & & & & & \\
\hline 34 & Lack of disclosure of applications arising from Open Data & & & & & & \\
\hline 35 & Provision of incomplete data & & & & & & \\
\hline 36 & Frustration with some information request's responses & & & & & & \\
\hline 37 & Transparency Portal features are slow & & & & & & \\
\hline 38 & Inability of government response to the volume of information demanded & & & & & & \\
\hline 39 & Interaction with other reference countries in Open Data & & & & & & \\
\hline 40 & Legal injunctions requiring not providing information & & & & & & \\
\hline 41 & Better understanding of how government works & & & & & & \\
\hline 42 & Better specification of open data documentation & & & & & & \\
\hline 43 & Improvement in the organization of government data as a whole & & & & & & \\
\hline 44 & Changing the culture of secrecy for a culture of access & & & & & & \\
\hline 45 & Need to articulate agreements with different agencies that own databases & & & & & & \\
\hline 46 & $\begin{array}{l}\text { Need for harmonization in the incorporation of Open Data principles } \\
\text { (policy and legal framework) }\end{array}$ & & & & & & \\
\hline 47 & Possibility of control and inspection of public agents & & & & & & \\
\hline 48 & Possibility of control and inspection of contracts and their additives & & & & \multicolumn{3}{|l|}{ Key: } \\
\hline 49 & Possibility to demonstrate that the government is efficiently spending its & & & & \multicolumn{3}{|c|}{ Type of Consequence } \\
\hline & limited resources & & & & \multicolumn{3}{|c|}{ Direct - Predictable - Desirable } \\
\hline 50 & Possibility of using Open Data for unclear purposes & & & & \multicolumn{3}{|c|}{ Direct - Predictable - Undesirable } \\
\hline 51 & Protagonism of the Open Data in the DF about other states & & & & \multicolumn{3}{|c|}{ Direct - Unpredictable - Desirable } \\
\hline 52 & Rapid creation of institutional framework to support Open Data & & & & \multicolumn{3}{|c|}{ Direct - Unpredictable - Undesirable } \\
\hline 53 & $\begin{array}{l}\text { State recognition that they do not have all the capabilities they would like } \\
\text { for problem-solving }\end{array}$ & & & & \multicolumn{3}{|c|}{ Indirect - Predictable - Desirable } \\
\hline 54 & $\begin{array}{l}\text { Restriction on the interpretation - to individuals capable of processing } \\
\text { data }\end{array}$ & & & & \multicolumn{3}{|c|}{\begin{tabular}{|l} 
Indirect - Unpredictable - Desirable \\
Indirect - Unpredictable - Undesirable
\end{tabular}} \\
\hline
\end{tabular}




\begin{tabular}{|c|l|c|c|c|c|c|}
\hline 55 & $\begin{array}{l}\text { Unions requested in court to not provide information about their } \\
\text { associates }\end{array}$ & & & & \\
\hline 56 & Requests for undue information (e.g., individual/private information) & & & & & \\
\hline 57 & Stress in the development team & & & & & \\
\hline TOTAL & $\mathbf{2 1}$ & $\mathbf{2 8}$ & $\mathbf{1 8}$ & $\mathbf{9}$ & $\mathbf{9}$ & \\
\hline
\end{tabular}

Source: elaborated by the authors.

Another use of the map is to observe the Stakeholder column directly. For example, the Passive column presents only Intended consequences (five observations), which makes sense since this stakeholder is by definition the farthest from innovation. In turn, the column that grouped Clients and Users presents many Unintended consequences (fifteen observations), which can be considered innovation improvement points. Finally, despite the previously described tendency of innovation supporters to see only the positive aspects of what they are trying to disseminate (ABRAHAMSON, 1991; ROGERS, 2003; SVEIBY et al., 2009), the Decision maker in this particular case is an exception to the rule and is aware of a number of difficulties arising from the innovation that he or she is driving, as shown in the column grouping the Decision maker's answers.

Thus, the collection of the views of different stakeholders on the same innovation generated a versatile and broad framework for the treatment of innovation that, without the participation of these different stakeholders, would be hard to obtain. These points are therefore reflected in theoretical contributions, given that they develop part of the DIT, with its connection with the Stakeholder Theory, indicating a direction for studies that address the consequences of innovation adoption. While this new mechanism of demonstrating the intended and unintended aspects of innovation provides a practical contribution to the innovation management, the Map of Consequences and, at least regarding the situation of open government data in GDF that was investigated, identifying the unpredicted consequences, can be used for learning and improving both innovation and its implementation process.

\section{FINAL CONSIDERATIONS}

Based on the assumptions of the Diffusion of Innovations Theory (ROGERS, 2003), this study aimed to identify the consequences of innovation adoption in the perception of different stakeholders' roles, contributing to studies in the field of innovations, especially in the development of an approach that takes into account not only the intended aspects of innovation, but also the unintended aspects that arise from it, in a broader perspective that goes beyond the pro-innovation bias. 
It was possible to achieve the general objective of this study, namely, to identify and categorize the consequences of innovation adoption in the perception of different stakeholders' roles, contributing to studies focused on innovation in a peculiar way, since, while it is unnecessary to emphasize positive aspects stemming from innovations, given the extensive literature on this subject (FAGERBERG, 2009; HALL; MARTIN, 2005), on the other hand, it is also important to recognize that there are negative aspects arising from innovations. This condition must be reflected, and the method developed here demonstrates empirically for the case of open government data adoption by the Federal District Government of Brazil that $43,2 \%$ of its consequences were deemed undesirable.

The study, therefore, contributed to the DIT, coupled with the Stakeholder Theory, and opens a new front for studies aimed at monitoring innovations that are largely concerned only with economic aspects or the economic versus social relationship. With the model, it is possible to analyze the numerous possibilities that the consequences of innovation adoption may have, such as psychological, social, political, technological and economic ones.

Still from the academic perspective, the study shows evidence that different stakeholders of an innovation can perceive differently the effects of the same consequence, which has the potential to explain the organizational phenomenon known as resistance to change (COGHLAN, 1993; TAMAYO-TORRES et al., 2016; TROSHANI; JERRAM; RAO HILL, 2011), as an action arising out of the conflict between these points of view. The survey also made it possible to raise a number of occurrences that can be treated as opportunities or threats by the researched organization, which can contribute to the efficiency in achieving organizational objectives and also to the literature on risk management (CLARKE; BECK, 1994; RAZ; HILLSON, 2005).

From a practical point of view, the method used in the study can be used to monitor the innovation process (TIDD; BESSANT; PAVITT, 2008), both in the private and public sector, since the Model for Analysis of the Consequences of Innovation Adoption developed here enables broad monitoring of the consequences related to innovation. For example, funding agencies concerned with the results of the initiatives that they support may find in this material a new perspective for monitoring their projects.

It is also necessary to recognize the complexity of the matter, expressed in numerous possibilities that the consequences of innovation adoption may bring about on multiple levels: individual, organizational and societal; and with effects that may vary over time. Also, the study synthesis can be viewed in a single image that reveals the similar and conflicting 
understandings of the different innovation stakeholders and can be used as an innovation management tool: the Map of Consequences of Innovation Adoption.

As to an agenda for future studies, another possibility to be explored would be to apply the concept of salience (MITCHELL; AGLE; WOOD, 1997) in studies on the list of stakeholders surveyed in the study, which can be used for further study of the influence of innovation stakeholders on the Decision maker. Yet another possibility would be to use the model to analyze the connections between the different stakeholders with regard to the actions of the User, contributing to studies that address its resistance (KLEIJNEN; LEE; WETZELS, 2009; OREG, 2003; OREG; GOLDENBERG, 2015).

The Model's comprehensive nature can also be used, together with theories that address the paradox of productivity (BRYNJOLFSSON, 1993, 2016), to analyze whether investments in Innovation and Communication Technologies (ICTs) produce other types of return to organizations that are not specifically related to resolving bottlenecks or expediting existing processes, such as innovations involving the participation of new agents, organizational arrangements, digital tools, management practices and business models, which can be combined to produce new goods, processes and services in both the private and the public sector (PINHEIRO; TIGRE, 2015).

\section{REFERENCES}

ABRAHAMSON, E. Managerial Fads and Fashions: the Diffusion and Refection of Innovations. Academy of Management Review, v. 16, n. 3, p. 586-612, 1991.

ASH, J. S. et al. Categorizing the unintended sociotechnical consequences of computerized provider order entry. International Journal of Medical Informatics, v. 76, n. SUPPL. 1, p. 21-27, 2007.

AXELSSON, K.; GRANATH, M. Stakeholders' stake and relation to smartness in smart city development: Insights from a Swedish city planning project. Government Information Quarterly, v. 35, n. 4, p. 693-702, 2018.

BARDIN, L. Análise de conteúdo. Lisboa: Edições, 70, 2011.

BAREGHEH, A.; ROWLEY, J.; SAMBROOK, S. Towards a multidisciplinary definition of innovation. Management Decision, v. 47, n. 8, p. 1323-1339, 2009.

BAWDEN, D.; ROBINSON, L. The dark side of information: overload, anxiety and other paradoxes and pathologies. Journal of Information Science, v. 35, n. 2, p. 180-191, 21 abr. 2009. 
BESSANT, J.; TIDD, J. Innovation and entrepreneurship. [s.1.] John Wiley \& Sons., 2007. BLOOMROSEN, M. et al. Anticipating and addressing the unintended consequences of health IT and policy: a report from the AMIA 2009 health policy meeting. Journal of the American Medical Informatics Association: JAMIA, v. 18, n. 1, p. 82-90, 2011.

BRYNJOLFSSON, E. The productivity paradox of information technology.

Communications of the ACM, v. 36, n. 12, p. 66-77, 1993.

BRYNJOLFSSON, E. Wired for Reshaping the Economy. 2016.

CABINET OFFICE UK. Open Data White Paper: Unleashing the PotentialPrinted in the UK for The Stationery Office Limited on behalf of the Controller of Her Majesty's Stationery Office. UK: [s.n.].

CLARKE, L.; BECK, U. Risk Society: Towards a New Modernity. [s.l: s.n.]. v. 73 COGHLAN, D. A person-centred approach to dealing with resistance to change. Leadership \& Organization Development Journal, v. 14, n. 4, p. 10-14, 1993.

DAWES, S. S.; VIDIASOVA, L.; PARKHIMOVICH, O. Planning and designing open government data programs: An ecosystem approach. Government Information Quarterly, v. 33, n. 1, p. 15-27, jan. 2016.

DE VRIES, H.; BEKKERS, V.; TUMMERS, L. Innovation in the public sector: A systematic review and future research agenda. Public Administration, v. 94, n. 1, p. 146-166, 2016. DE VRIES, H.; TUMMERS, L.; BEKKERS, V. A stakeholder perspective on public sector innovation: why position matters. International Review of Administrative Sciences, $n$. May, p. $002085231771551,2017$.

DESA, U. Open Government Data for Citizen Engagement in Managing Development Guidance Toolkit. p. 1-104, 2013.

DOSI, G. Technical change and industrial transformation. New York: Martin's Press., 1984.

FAGERBERG, J. Innovation: A Guide to the Literature. The Oxford Handbook of Innovation, p. 1-22, 2009.

FONTENELLE, I. A. Para uma crítica ao discurso da inovação: saber e controle no capitalismo do conhecimento. Revista de Administração de Empresas, v. 52, n. 1, p. 100$109,2012$.

FREEMAN, C.; SOETE, L. The economics of industrial innovation. [s.1.] Psychology Press, 1997.

FREEMAN, E. R. Strategic management: A stakeholder approach. [s.l: s.n.]. v. 1 FREEMAN, R. E.; REED, D. Stockholders and Stakeholders: A New Perspective on 
Corporate Governance. California Management Review, v. 25, n. 3, p. 88-106, 1983.

GONZALEZ-ZAPATA, F.; HEEKS, R. The multiple meanings of open government data:

Understanding different stakeholders and their perspectives. Government Information

Quarterly, v. 32, n. 4, p. 441-452, out. 2015.

HALL, J. K.; MARTIN, M. J. C. Disruptive technologies, stakeholders and the innovation value-added chain: A framework for evaluating radical technology development. R and D Management, v. 35, n. 3, p. 273-284, 2005.

JANSSEN, M.; CHARALABIDIS, Y.; ZUIDERWIJK, A. Benefits, Adoption Barriers and Myths of Open Data and Open Government. Information Systems Management, v. 29, n. 4, SI, p. 258-268, 2012.

JANSSEN, M.; CRESSWELL, A. M. An enterprise application integration methodology for e-government. Journal of Enterprise Information Management, v. 18, n. 5, p. 531-547, 2005 .

JETZEK, T. Managing complexity across multiple dimensions of liquid open data: The case of the Danish Basic Data Program. Government Information Quarterly, v. 33, n. 1, p. 89104, 2016.

KARO, E.; KATTEL, R. Innovation and the state: Thinking of government as "Technology Maker" and implications for public administration research. Administrative Culture, v. 17, n. 1, p. 5-17, 2016.

KATTEL, R. et al. Can we measure public sector innovation? A literature review. LIPSE Working Papers, n. 2, p. 2-38, 2014.

KLEIJNEN, M.; LEE, N.; WETZELS, M. An exploration of consumer resistance to innovation and its antecedents. Journal of Economic Psychology, v. 30, n. 3, p. 344-357, 2009.

MARKUS, M. L.; MENTZER, K. Foresight for a responsible future with ICT. Information Systems Frontiers, v. 16, n. 3, p. 353-368, 2014.

MITCHELL, R. K.; AGLE, B. R.; WOOD, D. J. Toward a Theory of Stakeholder Identifiction and Salience : Defining the Principle of Who and What Really Counts. Academy of Managemen, v. 22, n. October 2015, p. 853-886, 1997.

NELSON, R. R.; WINTER, S. In search of a useful theory of innovation. Innovation, Economic Change and Technology Policies, p. 215-245, 1977.

NELSON, R. R.; WINTER, S. G. An Evolutionary Theory of Economic Change. [s.l: s.n.]. v. 93

OBAMA, B. Memorandum on Transparency and Open Government. 2009, p. 21-22. 
OECD. Open Government: The Global Context and the Way Forward, OECD Publishing, Paris, 2016.

OGP. Open Government Declaration | Open Government Partnership, 2011. Available at: http://www.opengovpartnership.org/open-government-declaration (accessed: March 26, 2019).

OKF. Open data handbook. 2012. Available at: http://opendatahandbook.org/ (accessed: March 26, 2019).

OREG, S. Resistance to change: Developing an individual differences measure. Journal of Applied Psychology, v. 88, n. 4, p. 680-693, 2003.

OREG, S.; GOLDENBERG, J. Resistance to innovation: Its Sources and Manifestations. Chicago: The University of Chicago Press, 2015. v. 53

PINHEIRO, A. O.; TIGRE, P. B. Proposta de investigação sobre o uso de software no suporte à inovação em serviços. RAE - Revista de Administração de Empresas, v. 55, n. 5, p. 578-592, 2015.

RAZ, T.; HILLSON, D. A Comparative Review of Risk Management Standards. Risk Management, v. 7, n. 4, p. 53-66, 2005.

ROGERS, E. M. Diffusion of Innovations. 5th edn. ed. [s.1.] NewYork: Free Press., 2003. ROSENBERG, N. Inside the black box: Technology and economics. [s.1.] Cambridge University Press., 1982.

SADIQ, S.; INDULSKA, M. Open data: Quality over quantity. International Journal of Information Management, v. 37, n. 3, p. 150-154, 2017.

SAXENA, S.; JANSSEN, M. Examining open government data (OGD) usage in India through UTAUT framework. Foresight, v. 19, n. 4, p. 421-436, 2017.

SCHUMPETER, J. A. The theory of Economic Development. Cambridge, Massachusetts: Harvard University Press, 1934.

SVEIBY, K. et al. Unintended and undesirable consequences of innovation. XX ISPIM Conference The Future of Innovation, n. June 2015, p. 1-16, 2009.

SVEIBY, K. E.; GRIPENBERG, P.; SEGERCRANTZ, B. Challenging the innovation paradigm. [s.1.] Routledge, 2012.

TAMAYO-TORRES, I. et al. Organizational learning and innovation as sources of strategic fit. Industrial Management \& Data Systems, v. 116, n. 8, p. 1445-1467, 2016.

TARAFDAR, M. et al. The Dark Side of Information Technology. Sloan Management Review, v. 56, n. 2, p. 59-70, 2015.

TARAFDAR, M.; GUPTA, A.; TUREL, O. Special issue on "dark side of information 
technology use": An introduction and a frame- work for research. Information Systems Journal, v. 25, n. 3, p. 161-170, 2015.

THE WORLD BANK. Open Government Data Toolkit. 2014. Available at: http://opendatatoolkit.worldbank.org/en/ (accessed: March 26, 2019).

THIRY-CHERQUES, H. R. Saturação em pesquisa qualitativa: estimativa empírica de dimensionamento. Revista PMKT, v. 3, n. Outubro, p. 20-27, 2009.

TIDD, J.; BESSANT, J.; PAVITT, K. Gestão da Inovação. [s.l: s.n.].

TIGRE, P. B. Gestão da inovação: a economia da tecnologia no Brasil. Rio de Janeiro, RJ: Elsevier, 2014.

TROSHANI, I.; DOOLIN, B. Innovation diffusion: a stakeholder and social network view. European Journal of Innovation Management, v. 10, n. 2, p. 176-200, 2006.

TROSHANI, I.; JERRAM, C.; RAO HILL, S. Exploring the public sector adoption of HRIS. Industrial Management \& Data Systems, v. 111, n. 3, p. 470-488, 2011.

VOS, J. F. J.; ACHTERKAMP, M. C. Stakeholder identification in innovation projects: Going beyond classification. European Journal of Innovation Management, v. 9, n. 2, p. 161-178, 2006.

WOLFE, R. A. Organizational Innovation: Review, Critique and Suggested Research Directions. Journal of Management Studies, v. 31, n. 3, p. 405-431, 1994.

ZUIDERWIJK, A. et al. Issues and guiding principles for opening governmental judicial research data. Lecture Notes in Computer Science (including subseries Lecture Notes in Artificial Intelligence and Lecture Notes in Bioinformatics), v. 7443 LNCS, p. 90-101, 2012.

ZUIDERWIJK, A.; JANSSEN, M. The negative effects of open government data investigating the dark side of open data. Proceedings of the 15th Annual International Conference on Digital Government Research - dg.o '14. Anais...New York, New York, USA: ACM Press, 2014a

ZUIDERWIJK, A.; JANSSEN, M. Open data policies, their implementation and impact: A framework for comparison. Government Information Quarterly, v. 31, n. 1, p. 17-29, jan. 2014b.

ZUIDERWIJK, A.; SHINDE, R.; JANSSEN, M. Investigating the attainment of open government data objectives: Is there a mismatch between objectives and results?

International Review of Administrative Sciences, 2018. 